\title{
Pacifying Police Units and private interests in Brazil
}

\author{
Las Unidades de Policía Pacificadora y los intereses privados en Brasil \\ MAYANE DORE \\ Macquarie University, Australia \& Complutense University, Spain \\ GABRIEL BAYARRI \\ Macquarie University, Australia \& Complutense University, Spain \\ DANIEL MARÍAS \\ University Carlos III of Madrid, Spain
}

\begin{abstract}
This article analyzes a concrete policy in the framework of Brazilian Public Security: the Pacifying Police Units (UPPs). It describes this policy and justifies, through an ethnographic case study, how the so-called "pacification of the favelas" articulates a logic of neoliberal urbanism and police infrastructure, understanding the residents of the favelas as potential consumers of their services. The article contextualizes the UPPs model as a paradigmatic case of public security in Latin America in which the discourse of violence/pacification is the main catalyst for private investments. More specifically, the article demonstrates how private companies resort to proximity conflicts mediation as a way of avoiding the judicialization of conflicts with the residents after the "Pacification". With this case, we expect to illustrate the patrimonialism and clientelism that shapes the Brazilian State and its ambiguous relationships between private and public interests.
\end{abstract}

KEYWORDS: UPP, Brazil, Conflict resolution, Patrimonialism.

RESUMEN: Este artículo analiza una política concreta en el marco de la Seguridad Pública Brasileña: las Unidades de Policía Pacificadora (UPPs). En el artículo se describe esta política y se justifica, a través de un estudio de caso etnográfico, cómo la llamada "pacificación de las favelas" articula una lógica de urbanismo neoliberal y de infraestructura policial, entendiendo a los residentes de las favelas como consumidores potenciales de sus servicios. El artículo contextualiza el modelo de las UPPs como un caso paradigmático de seguridad pública en América Latina en el que el discurso de la violencia/pacificación es el principal catalizador de las inversiones privadas. Específicamente, el artículo demuestra cómo las empresas privadas recurren a la mediación de conflictos de proximidad como forma de evitar la judicialización de los conflictos con los vecinos después de la "Pacificación". Con este caso se pretende ilustrar el patrimonialismo y el clientelismo que conforman el Estado brasileño y sus ambiguas relaciones entre los intereses privados y públicos.

Palabras ClaVe: UPP, Brasil, Resolución de conflictos, Patrimonialismo.

Recibido: 10 de octubre de 2020. Aceptado: 30 de octubre de 2020.

Revista de Estudios en Seguridad Internacional, Vol. 6, No. 2, (2020), pp. 137-153. http://www.seguridadinternacional.es/revista/

ISSN: 2444-6157. DOI: http://dx.doi.org/10.18847/1.12.8 


\section{INTRODUCTION $^{1}$}

By focusing on the theme "Instruments for Interference in the Performance of the Brazilian Judiciary", the article focused on the elaboration and development of an ethnographic research about the institutional forms of conflicts administration in the State of Rio de Janeiro, giving special emphasis to the police administration of conflicts and the private corporation interests in this model. The fieldwork was conducted during the years 2013, 2014 and 2015, and the final data analysis was updated in 2020 for this article.

The political program that articulates our argument is the Program of Mediation in Favela $^{2}$ served by the Pacifying Police Units (from now on UPPs), an initiative that seeks to train the Policia Militar (Military Police officers, from now on PM) to exercise, with the use of proper judicial mediation techniques, the role of mediators of proximity conflicts in the so-called favelas. The initiative is part of a cooperation agreement, signed between the Court of Justice of the State of Rio de Janeiro and the Secretary for Public Security of the State of Rio de Janeiro in 2011, whose purpose is to apply alternative conflict resolution mechanisms to reduce the "judicialization" of disputes between local residents.

This program is part of a framework in the judicial field that, since the 90's of the 20th century, draws on the principles of mediation and conciliation and that, in this case, concedes this task to the local police with the claim of "reforming" the institution. In this sense, the UPPs emerge as a means to "pacify" the so-called favelas and its internal conflicts. At the moment the police occupy these favelas — which have long lived "under the aegis of parallel power"- new normal conflicts in democratic societies emerge (Colonel Robson Rodrigues, former Commander of the UPPs), and new tools, such as mediations, must be applied to deal with these conflicts.

The article analyzes this policy within the framework of Brazilian Public Security. It describes the policy and justifies, through an ethnographic case study, how the so-called "pacification of the favelas" articulates the logic of neoliberal urbanism and police infrastructure, understanding the residents of the favela as potential consumers of new services. In this sense, it explores the capture of the State by two main levels: a wider level, during the decision-making process, in which neoliberal urbanism works towards a global finance system seeking to (re)invest surplus value; and the instrumentalization of mediation that favors private interests. Through the latter, the center of this article, we demonstrate how these companies resort to the proximity conflict mediation as a way to avoid the judicialization of conflicts with the new existing consumers, and as way to "pacify" potential conflicts in a win-win situation.

The article argues that proximity conflict mediations have the concrete role of, on the one hand, helping in the performance of the Court of Justice to reduce bureaucracy and paperwork, and on the other hand, preventing disorder. For the police ethos, we must highlight that mediations are important insofar as they can prevent "potentially violent" conflicts, that is, "legitimate" conflicts to be fought under violent logics of war.

A key aspect of this process, and central to the argument of this article, is the private interest of companies like Light (energy sector) or CEDAE (water and sewerage

\footnotetext{
${ }^{1}$ This article presents the results of an ethnographic research conducted for the project "Instruments for Interference in the Performance of the Judiciary", supported by CAPES (Coordination for the Improvement of Higher Education Personnel)/CNJ (National Council of Justice).

${ }^{2}$ Favelas are the Brazilian native category to refer to human settlements, particularly in the city of Rio de Janeiro.
} 
company), in this model. For these companies, the possibility of solving customer conflicts through mediation, and thus preventing further lawsuits, supposes an enormous reduction in judicial expenses, particularly in litigation costs. Moreover, the model tends to put the company in a position of advantage given its higher power of bargaining that forces customer to agreements in a win-win situation. As a result, the case demonstrates how the Brazilian State -within its economic, political and cultural postcolonial context - understands favela's dwellers as "second-class citizens", and therefore, as potential customers of companies seeking for profit in these "pacified"" spaces. More than citizens of rights, residents are customers.

Finally, the article argues that this neoliberal logic lays the foundation for the slow decomposition of the program, alongside its ostensibly pacifying and harmonic approach to urban violence. The Pacifying Polices Units are part of a spectacular logic of projecting Brazil and Rio de Janeiro as a business friendly city, where security would not be a problem. However, since the military intervention in the State of Rio de Janeiro in 2014, a new logic has emerged, revealing to international community that, underlying the harmony and cordiality performance, was a profoundly violent society, with deeply a rooted inequalities, and structural racism; issues never seriously addresses by the UPPs policy. As a result, in the last years the local and federal governments shifted to a hardline agenda against drugs dealing in the favelas, increasing a military performance that grounds the rise of the far-right in the country. This shift, we suggest, exposes the deficits of the UPPs policy and its unfulfilling promises of offering, alongside policing, public investments in areas such as education, health and sanitation.

Our analysis draw on various scholars that constitute the so-called "Brazilian Social Thought"; authors who have worked specifically on the relationship between the Brazilian State and the private corporation interests. Scholars such as Florestan Fernandes, Darcy Ribeiro, Caio Prado Jr, Victor Nunes Leal, Sergio Buarque de Holanda, Gilberto Freyre, and Raymundo Faoro provide us a conceptual framework in which the condition of Brazil as a post-colonial State emerge as fundamental aspect to understand its patrimonialist relationship between common resources (represented in the State) and particular interests.

Since the colonial period, the construction of the Brazilian State was instrumentalized to serve the particular interests of colonizers. The contemporary period holds powerful traces of this reality. One example is the institution of the Military Police, which we analyze in this article, that was created to defend the imperial interests of settlers and slave-owners in Brazil. The reality of current time is that this institution, like so many others in public administration, continues to maintain its foundational logics and purposes, that is, criminalize the working-class while protecting the privileges of the elite. In this light, the UPPs express this patrimonialist character of Brazilian Post-colonial State.

The Brazilian literature defined these patrimonial relations through different concepts and analytical categories, adapting it to the different periods, geographical regions and local realities. But they are all fundamentally grounded on the relations between the private and the public spheres in the Brazilian State: the "Bureaucratic estament", defined by Raymundo Faoro (1958), refers to the structure of patrimonialism power in the State. "Coronelismo" ("Colonelism") was first applied by Victor Nunes Leal (1948) to refer to the power and violence exercised by the figure of the Colonel during the "Old Republic" (1889-1930) in Brazilian municipalities, that built, at the same time, a network of interests with national institutions. In other words, both levels, local and national, were connected and mediated by the figure of colonel. In addition, the category "clientelism" has been 
widely disseminated since the work of Benjo Galhart (1964), to refer to the unofficial exchange of favors between various close actors with political interests, as well as between different administrative levels. In this sense, "clientelist" relations occur both horizontally and vertically. Lastly, "Mandonismo" is a purely Brazilian concept, which could be approached in Spanish-American literature as "Caciquismo". This concept refers not to a system, but to the characteristic of a traditional political figure: the "mandão" i.e., the one that orders - as a figure that exercises and concentrates power in an oligarchic and personalized structure.

The purpose of indicating these concepts is not to try to detail or analyze the validity of each of these concepts as analytical category in our article. In fact, we start from the premise that these are entangled concepts that occurs simultaneously. What we look for to demonstrate is the extensive work already produced in the Brazilian literature in order to understand the specificities of its State formation in regards to public and private interests. In doing so, we highlight the underlying framework of our work, as well as the logics and ideologies sustaining the practices and institutions here analyzed. In this sense, the empirical case explored in this article is not an isolated case, rather, it is part of a wider historical process of private interests (in this case private companies) and the State.

\section{Structure of the article}

We organize the article in 3 central parts: in the first part, "Neoliberal urbanism and pacified cities", we contextualize the project of the UPPs in a wider context of neoliberal urbanism and transnational cities. The section argues that the case of Rio de Janeiro is a paradigmatic case in Latin American security policies in the ways it demonstrates how global financial market dynamics are articulated at the local level via urban interventions and public security policies. In the second part, "UPPs and proximity conflicts mediation", we introduce the policy of the Pacifying Police Units, the program of proximity conflicts mediation, and we analyze an ethnographic case study of conflicts mediation between local residents and private companies conducted by the Military Police in a "pacified" favela. In the third section, "The relationship between private companies' interests and the State in the favelas", we explain how the State-business interest framework is produced, which uses the residents of the pacified favelas as potential consumers of their services. The article concludes arguing that the companies use the State infrastructure to give continuity to their private interests of cost and profit reduction. And that, in this sense, they use the most effective strategy according to the correlation of forces, whether these are more preventive of the conflict (as in the case of the UPPs) or are explicit in the mechanisms of violence (as in the military intervention and the rise of the far- right).

\section{NEOLIBERAL URBANISM AND PACIFIED CITIES}

The UPPs model in Rio de Janeiro is an illustrative case of how global financial market dynamics are articulated in the territory through urban planning interventions and security policies. The effects of the "pacification" model still resonates in the streets of this city, becoming a paradigmatic case of security policies in Latin America, where the discourse of pacification and urban renewal are the main catalysts for private investment in the city. In this section we contextualize how the case of the city of Rio de Janeiro fits into a broader process of global cities guided by a model of neoliberal urbanism, and how in Latin America, the issue of security emerges as a central theme for this model. As a result, 
we highlight a first level of capture of the State by corporate interests, that is, in the decision making of the city of Rio de Janeiro.

In a context of growing competition for private investments between cities, megaevents such as the Olympics or the World Cup are pivotal opportunities for the projection of the city as a cosmopolitan symbol, as a transnational reference and an icon of hospitality in the international context. It is the opportunity to strengthen its global characteristics as a welcoming city (Pujadas, 2005), orienting itself towards the international flows of capital and investment, people and services, often diverging from the internal interests of its citizens.

The mega-events emerge as an opportunity for metropolitan expansion and symbolic redefinition of former industrial, port and peripheral areas. Low-income areas, such as the favelas, are thus under strong pressure from actors interested in acquiring these emblematic spaces to consolidate a project of global visibility and capital accumulation. As a result, authors such as Pujadas and Baptista (2000) point to an explosion concomitant to an implosion: an explosion of cities in order to obtain a higher position in the dispute of world metropolis; and an implosion within them, producing new conflicts and a radical change in spatial references, in the rules of sociability and local behavior.

Especially relevant in this process is urban planning, and in particular, the neoliberalization of urban planning in recent decades. Faced with a growing and challenging competitiveness among cities, alongside the retraction of public investment in a context of globalization, urban planning and urban renewal become central to attracting national and foreign capital. As a result, the phenomenon of neoliberal urbanism is also characterized by the active role of local governments in urban policies.

As stressed by Franquesa (2013), urbanism is a set of knowledge, practices and discourses that operates on instances of power and can act to organize the geography of capital. As such, neoliberal State gain a prominent role in organizing such geography through local urbanism. Rather than act as passive and external actors that search to unleash market forces, in the neoliberal urbanism project states emerge as a key actor, including its institutional framework, policy regimes and regulatory practices (Brenner \& Theodore, 2002). Mechanisms such as financial and tax support, deregulation, flexibility of planning controls, the creation of mixed capital corporations and public/private partnerships, or localized ongoing investments that increase land value are some of these examples.

The 2008 global finance crises exposed another ongoing dimension of this process: the financialization of urban politics. As Rolnik (2015) highlights, in the last decades, the primordial motor of the financialized neoliberalism has been a real estate market that offers mortgages and shares of international funds as part of their finance products. Considering that urban redevelopments progressively rely on private and international finance, governments are led to create the conditions for investments, transferring part of its decision-making process to global instances. In this sense, private interests -in this case multinational and finance market - becomes primordial in the definition of land use, in detriment of public interests.

\section{FAVELAS, OLYMPICS AND THE SECURITY CRISIS}

In this context of globalization and neoliberal urbanism, the 2016 Olympics Games and 2014 World Cup granted the city of Rio de Janeiro the historic opportunity to attract investors from all over the world, and projecting itself as a welcoming metropolis capable 
of hosting worldwide mega-events. However, to make this image concrete, it was necessary to overcome an important stigma of the city: the so-called "public security crisis", which for years has been associated with the "problem of the favelas" (Zaluar \& Alvito, 2006). In other words, the favelas should be pacified, inaugurating like this, the UPP programme.

Here it is important to highlight that it was at the beginning of the 20th century that the favelas began to be identified by public authorities and the local mass media as the privileged locus of crime and misery, and therefore a problem for the city (Benchimol, 1990; Valladares, 2005; Vaz, 1994). This form of approach to the favelas, however, seems problematic as it reduces the problem of urban violence to the context of the favelas, criminalizing poverty and reproducing structural racism in a post-colonial and postslavery city. And yet, it is precisely this perspective that inaugurates a grammar of social control of the favelas; a grammar that juxtaposes the urbanization of these spaces with the presence of the police and as a form of "managing" the favelas.

It is in this intersection where the welcoming cities, the favelas, the Olympic Games and the public security policies converge, generating an ambitious program of public intervention - the UPPs - based on what Cavalcanti (2013) calls the spectacle of integration. According to the author, in the urban interventions of this period, the rhetorical and aesthetic emphasis is placed on the presence of the State in the favelas, on the connection and incorporation of the latter into the so-called "formal city" 3 . In this way, the insertion of this space in the city's landscape inaugurates an ambiguous regime of (in)visibility of the favelas, given that it is the union - illustrated by the ostentatious bridges and cable cars that connect the favelas with the rest of the city - that stands out in our eyes, instead of the favela as an autonomous space whose own identity is reaffirmed and recognized.

In this context, if before the favela was a problem, an impediment, it is now an opportunity. The opportunity to re-signify these stigmatized spaces that contradict the welcoming project of global cities and to integrate them into the so-called "formal city". But above all, it is an opportunity to integrate an informal economy into formality, to generate wealth and new business opportunities. The pacification is now the promise that feeds the speculation around the pacified areas, and invites private interests to join.

A remarkably example of this logic is the final definition of the areas that would host the UPP programme. The map of the spatial distribution of the UPP units indicates that they are concentrated on the rich and touristic area of the city - the Zona Sul-, and the sites for Olympic games — stadiums, pools, etc. In this light, the so-called "Olympic Belt" illustrates this new model where urban politics and public security policies are shaped by private interests, and where the pacified areas become privileged areas for business.

\section{UPPS AND THE MEDIATION OF PROXIMITY CONFLICTS}

The Pacifying Police Units programme started on 2008. As we argue in this article, it was the result of a public security policy that articulated ambiguous interests of both State's interests in "pacifying" the favelas - historically perceived as the origins of urban

\footnotetext{
3 The opposition between the concepts of "formal city" and "informal city" are local terms that must be understood as part of the space production of the favelas. More than an objective and purely economic vision, they are the reflection of a particular conception of the forms of labor and social relations; the result of a hierarchical social map of the city that is built from the moral opposition between the hills of the favelas and the "asphalt" (the asfalto); the formal and the informal; the presence and the absence of the State.
} 
violence - and private companies interested in the land value of these areas, as well as new customers for the not yet formal (and thus unpaid) services of energy, water, telecommunication, etc.

In order to justify this idea, in this section we will introduce the formal policy of the Pacifying Police Units and its underlying logics and sociology. In this section we look for to highlight the paradoxical implications of having these units as part of a military police, and the specific program of conflict mediation as a tool of administration of conflicts that favors business interests. In doing so, we analyse this case as a paradigmatic representation of the patrimonialist and clientelist dimension of the Brazilian State that actively collaborates in the defense of private interests.

To explain the UPPs, it is worth pointing out that it was during the United States Civil Rights movement in the 60' when a strong opposition against the repressive forces of the police emerged. The movement denounced the use of violence against Black people, and other criminalized groups at the time, leading to the beginning of a call to the so-called "community police". Different from the ostensive and repressive policing model, the community police would be more involved with social groups, working towards prevention, rather than suppression. Following this event, the U.S. community police model would be exported internationally, and Brazil would try to adapt these principles to its local reality (Melo, 2009).

This historical and international influence, in addition to the neoliberal logics applied to urbanism already explained in the first section, were key to the ambitious plan of the Rio de Janeiro State Security Secretariat to pacify the favelas of Rio. In the following lines, we will explain the functioning of the UPPs work.

Beginning in 2008, the project was initially taken to 38 favelas, out of the more than 1000 existing favelas in the State of Rio de Janeiro ${ }^{4}$. The UPPs follow two main criteria to select the favelas that would host the programme. The selected favelas should always be: 1) poor favelas 2) highly informal 3) with the presence of heavily armed criminal groups (Nascimento, 2013). In the process of implementation, the first step before the inclusion of the UPP is the tactical intervention, carried out by the Special Police Operations Battalion (BOPE) and/or the Shock Police Battalion, with the objective of recovering State control over areas illegally dominated by highly armed criminal groups. Once "conquered", the BOPE rises on the recently "dominated" favela its controversial black flag of a skull with two guns crossing its head. It is with this warlike performance and violent symbolism that the so-called "pacification" begins.

After the public demonstration of domination, the police undertake an extensive operation to dismantle the previous system of "disorder" - in the police terms - in order to generate a new order, the police order. Stabilization, implementation, and control are the three steps undertaken by the military police who will form the UPP.

The new UPPs' functions are divided between the "Pacification Police Group" (GPP), in charge of patrolling the favela and reinforcing its sense of presence; the Pacification Police Tactical Group (GTPP), which supports the former in critical situations; and the administrative sector (Luci de Oliveira, 2012). The police officers who are part of the UPPs receive extra training in areas such as human rights or citizen police. It is a course comprised six modules: social protection; first aid; urban space management and gender; youth and sexuality. This complementary training is intended to shift the warlike and punitive-repressive mindset that characterizes the PM (Nascimento, 2013). As an

\footnotetext{
${ }^{4}$ Source: FAFERJ -Federation of State of Rio de Janeiro Slums Association.
} 
extended issue within the corporation, police training often emerges as central component to change policing strategies, deeply significant to the profile of Brazilian police, particularly the Military Police (Kant de Lima, 2003).

However, as Kant de Lima (2003) argues, police training centers are only partially capable of shaping representations and building knowledge among security officers. In the police, the knowledge acquired in the training centers share space, or is even ignored, by the knowledge acquired "in practice", in the daily life of the streets, not infrequently transmitted by older police officers (Monteiro \& Malanquini, 2012). The Secretariat of Security, being aware of this reality, promotes the construction of a young and new pacifying police force, whose policemen can acquire new knowledge in the practice of their service.

The legal approval of the UPPs came in 2009 when the PM's bulletin formally announced the annexation of the UPP program to its body, and an extra R $\$ 500$ bonus (around 100 USD) for policemen who had to work in the recently pacified favelas, being the Morro de Santa Marta, in the south and rich area of Rio de Janeiro, the first where this security policy was applied.

However, the proximity police did not emerges with the current Pacifying Police Units in the favelas. The need to integrate the police and the favela population through collaborative actions had already been worked on previously through two programs: the Grupo de Aplicação Prático Escolar (School Practical Application Group: GAPE) and the Grupos de Polícia em Áreas Especiais (Police Groups in Special Areas: GPAEs), completely new to the PM. None had continuity. (Luci de Oliveira, 2012).

It was during Leonel Brizola's first term as Governor of the State of Rio de Janeiro, in 1983, when a first attempt was undertaken to break with the repressive logic of the military dictatorship.

His government firstly introduced into the public debate the failure of military police to respect human rights, polarizing the discussion between the defenders of "social discourse" and the "repression discourse". In this context, a new concept emerged: the Public Policy of Security Policy, which understood public security in a broader sense, integrated to other social dimensions of life (including for instance health and education), rather than isolated areas responsible for responding to isolated events exclusively in terms of policing.

Drawing on this concept, the UPPs, as the third attempt to pacify the favelas, sought an integrated policy capable to articulate public security policies with other policies that conceive formal citizenship to the residents of favela; policies such as education and local sanitation. This is a transition from a public security policy to Public Policies of security (Luci de Oliveira, 2012).

The UPPs are part of this historical process, built under a strong opposition: on one hand, constituted by a Military Police with a brutal history of violence, trained under a logic of war, the "logic of extermination" of conflict and fighting the enemy; and on the other hand, originated in a context where new forms of community police are vividly debated, looking to treat security as a public, integrated policy.

Due to this delicate balance, the constancy in the objectives of the UPPs, as an integrated policy, was always very difficult to keep. In the last decade, we have observed how the UPPs have become the political means of an absolute representation of the State within the favelas - and often an authoritarian representation-, without offering the other promised basic services, apart from Military Police. In daily practices, the UPPs 
management has acquired totalitarian traits in the process of democratization of social relations (Luci de Oliveira, 2012), meaning that the PM is still subject to a State order, instead of civil order.

\section{The mediation of proximity conflicts}

The Program of Mediation of Proximity Conflicts in the favelas, undertaken by the UPPs, is an initiative that trains police officers to act as mediators of proximity conflicts in the favelas of Rio. The purpose of the programme is to apply alternative forms of conflict resolutions in order to reduce the "judicialization" of disputes between local residents and neighbours, as well as to reduce the gap between the institutions of justice and the overall society.

The service is shaped by the principles and techniques of direct mediation, in which justice is achieved through "reasonable solutions", in accordance with the cultivation of dialogue as a form of dealing with conflicts. In this sense, in the mediation processes, the parties involved are the ones responsible for reaching an agreement.

However, alongside the pacification stage previously described, comes the first barriers and challenges to the application of such principles, the first "clash of order", that is, the adaptation process to the new rules, rights, and duties between the favela and the State representation in the favela (i.e., the Military Police). This "clash", we suggest, can alter the impartiality of the mediation processes: on the one hand, the condition of the favelado 5 as an incomplete citizen - that is, a concept of citizenship grounded on tutelary logic in which rights are perceived as concessions - makes him/her a vulnerable individual in the face of possible arbitrations. On the other hand, the condition of the police as representatives of the State grants them a tutelary behavior that challenges the impartiality of mediation mechanisms. In addition, rigid military hierarchies lead to a lack of autonomy of the police officer while mediating different case; the evaluation of his/her role is measured in term of his obedience to superior orders, rather than his social and creative ability in dealing with each particular case (Kant de Lima, 2003).

In mediations, many problems arise from the lack of knowledge of "asphalt" rules, of the non-favelado; and the police, as the German philosopher Hegel would say, is still knowing the "living good that protects" (Hegel, 2003), so they expect an "asphalt behaviour". Each PM at the UPP is also acting as an educator, psychologist or lawyer. The State is only present in the favelas in the field of security, and this situation brings as a consequence the hypertrophy of the role of the police, having to appropriate different functions, among them the office of mediation.

The existence of conflicts is not necessarily a negative phenomenon, since conflicts show that there are incompatible interests, a fundamental factor in every process of democratization. In the study of the cosmology of conflict, we problematize the ways in which it is resolved, the possible arbitrariness latent in its resolution, and its peaceful resolution. Nevertheless, conflict is a necessary component of human interaction, and the emergence of conflict can be understood in the context of pacification as a form of freedom, of access to the citizen's right to freedom of expression. With more freedom, different opinions necessarily arise (Luci de Oliveira, 2012).

The PM ethos is guided by the logic of extermination of conflict and enemy combat, and conflict resolution has, according to native principles, a peripheral place to police

\footnotetext{
${ }^{5}$ Favelado is the category used to refer to residents of favela.
} 
action. Conflicts between neighbours, relatives, etc. are conceived by policemen as "feijoadas" ("beans"), with less importance than the "real conflicts" (such as the fight against trafficking).

It is fundamental to continue reflecting about how the PM appropriate, resignify and reinterpret the principle of "mediation" in the treatment of proximity conflicts in the "pacified" favelas. The PM, through the mediations, finally becomes a piece that benefits the companies after the Pacification, in a system that sees in the favelas a potential niche market.

\section{A concrete case study: State actors and business interests}

In this section, we draw to ethnographic data, as part of our fieldwork with the Military Police of a Pacifying Police Unit. Through the case study, based on participant observation and in-depth interviews, we intend to show a central point: the instrumentalization of mediation, here employed as a facilitator of private companies' interests inside the favelas. As the Military Police officers themselves acknowledge, the police institutions become key actors in this process where justice serve the interest of private companies instead of residents' interests, and the State becomes captured by private interests.

The Military Police officer, Luciana Pereira, is in charge of the mediation of conflicts between residents that live on the top of the favela. We meet at the local UPP unit, where the mediation normally occur, so she can show us how she classifies the conflict mediation. The moment occurs shortly before the beginning of the dismantling of the UPPs in 2016, a process that continues until today, the year 2020.

The Military Police team explains to us that "the companies are delighted with the service of the mediation of proximity conflicts". According to them, the mediation reduce the costs for companies, as they can achieve favourable agreements - through the mediation of police officers - , rather than paying high amounts of indemnisation to residents. Moreover, in this model dwellers must comply with a certain order and a state of harmony, as expressed in the ability of achieving agreements, that avoids expensive judicial conflicts. Because of that, companies like Light, a private company that manages the energy of the favelas since the beginning of the pacification ${ }^{6}$, have direct agreements with the UPPs. This way, when contacted by a resident or a Registry of Occurrence, the UPP unit calls Light and arrange a mediation.

Since this is a service provided by a company with a private concession, "Light benefits from such low-cost resolution" - the PM explains to me- and is indirectly funded by the State's mediation.Light also benefits from these mediations through collective mediation processes, in which many residents, affected by the poor quality of light and energy services, reach their agreements at the same time. This means enormous savings in additional costs for the company.

Different from Light, CEDAE, the Rio de Janeiro State Water and Sewerage Company, partially privatized, do not have a partnership with UPP. Nevertheless, it still uses the services through the Ministry of Justice, as it also clearly benefits from non-

\footnotetext{
${ }^{6}$ Before the process of pacification, many residents had irregular usage of energy, the so-called "gatos", where residents could use the energy from public spaces (e.g. street light) without necessarily being a registered as customers who formally pays for the service.
} 
conflicting agreements. In the words of Luciana, "it is much cheaper because you always have a poor policeman to do the service".

According to different Military Police, these companies have many problems in the pacified favelas because they do not offer a good quality service. To solve the high amount of issues, they usually establish a manager responsible for the conflicts mediated by the Military Police and prevent the opening of legal complaints. In this process, residents associations also become crucial intermediary organizations for dwellers who lack further legal knowledge.

The contemporary State strategy in the UPPs is transforming the management of conflicts, as it avoids lawsuits and prizes consensus. In general, the weakest participants seek the law and the strongest ones seek negotiation (Nader, 1994), and the companies that positioned themselves in the market niche of the pacified favelas are the first to benefit from the previous resolution regarding the assumption of costly denunciations. "We have carried out a massive mediation with Light, with several buses of people affected by the company's service, approximately 500 people against a company representative", says a PM. Thus, the importance is the ability to solve conflicts and not injustices. In this model, the citizens are understood as "patients" who need help. As people unable to assert their legitimate interests (Miranda \& Dirk, 2010), and the UPP establishes a resolving assistentialism based on a PM that is not used to work with proximity and community techniques.

My interlocutor also explains to me that the pacified favelas do not have an agreement between the UPPs and the Civil Defense Secretatiat of the State of Rio de Janeiro. According to her, the UPP guarantees, with the strategic support of the mediations, the investment of private companies in the favelas. This, of course, is understood at a level of relations in which the individual-PM is only part of the machinery of power in the final instance. The PM only has to carry out the mediation and convert the conflict into an "agreement", and reduce the expenses of the company that is intervening in the conflict.

Luciana even says that "in this agreement between the Court of Justice and the Secretariat of Security, I believe that only the first one wins". With this sentence she is saying that the Court of Justice would see in the mediation of conflicts the possibility of receiving fewer demands from judicial processes, while the PM would assume the performance of the mediation of conflicts as part of the interest of the companies.

According to the lieutenant of another UPP, the mediation agreement at the UPPs has for the institutions a first purpose of debureaucratizing the Court of Justice and generating interests to large companies. For the Secretariat of Security the advantage would be to prevent the greatest conflict.

Conflicts with large companies, such as Light or CEDAE, are constant and numerous. These meetings are held with representatives of the company and all the inhabitants affected to reach an agreement. Thus, the case is stopped until gathering a certain number of demands that justify the organization of a general mediation, which generally concludes with a commitment of improvement by the company and avoids the judicial conflict.

\section{The relationship between private companies' interests and the State in the favelas}

Proximity conflict mediations have the concrete role of, on the one hand, helping in the performance of the Court of Justice to debureaucratize the offices. On the other hand, 
mediations prevent bigger conflicts that can create a disorder in the system that the UPP is trying to build. This purpose coincides with the behavior of a community police force that must fight disorder as a premise of its "ethos", and with the Secretariat of Public Security, which tries to prevent the statistical growth of crimes and homicides in their prevention. In this framework of benefits, the inventors of the service do not pay too much attention to the effectiveness of the mediation itself. The last piece in this picture, which is the central piece in this article, are the concessionary or private companies present in the favela, such as the company Light or CEDAE, for which the resolution of the conflict prior to the transformation into a judicial complaint supposes an enormous reduction in judicial expenses, specifically in the expenses of litigation.

The new mediation mechanisms are presented with more restorative and less punitive results (Garland, 2008), and are more interesting for the reformist spirit than for the impact on the functioning of criminal justice. Laura Nader (1994) expresses this ideology with a sentence used by her Zapotec interlocutors: "más vale um mal arreglo que una buena pelea" ("is better a bad fix than a good fight"). The judicial system and the new UPPs are interested by the same harmonic ideology: the judicial system because of the saturation of demands. And the UPPs as they try to establish two principles of the community police: autonomy in their units to act according to social realities and conflict prevention as part of the classic repressive culture.

The Court of Justice tries to reduce bureaucracy through mediation. The conflict first seeks to be resolved through mediation. If it does not reach an agreement, the second level in the "struggle for harmony" is the judicial process. In any case, the organizing agents of the service bring benefits: if the resolution does not occur according to the logic imposed by the State to solve potential conflicts, the following steps will end the conflict (judicial process), because the logic of the State imposes itself.

It should be highlighted the importance given to the concrete maintenance of the UPPs in the favelas near the rich areas, which as part of a speculative project, have been treated to maintain for a decade. Finally, the project demonstrated the impossibility of a PM based on the repressive-punitive logic and on in the defense of private interests to create social justice in the favelas. These favelas have been deceitfully trying to impose themselves as an extrapolated model to other favelas, with other realities, where the UPP has not achieved hegemonic power, but which fulfills its function in the logic of the interests of the State and of companies through the power game.

The presence of bocas de fumo, the points of sale of drugs, in certain favelas dilutes this concrete image throughout the rest of the favela and thus conforms an imaginary territory as a vast homogeneously crime space. The policies applied are consequences of this imaginary and react to it in a uniform way throughout its territory, in all the favelas. The term favela is therefore very harmful for the application of a homogeneous policy, since any place without the presence of the State, but with the presence of armed trafficking, will automatically be a favela, the same as the rest and treated equally rigidly, without the pertinent flexibility of the differences and social realities in each of them. Thus, the term favela encompasses diverse realities, diverse sizes, diverse populations, and the UPPs' security policy is blind to this profile and reduces to its essence its classification system, which contemplates the favela as space where "poor, potential criminals" live (Misse, 2010) and where the companies can make profiles.

In this way, the favela stands as space where the conflicts of the stigmatized are concentrated and managed, where fences can receive a concentrated security policy from the State. The creation of a border between the spaces, called native categories of 
"asphalt" and "favela", generates a caste barrier, which by generating a group of excluded minorities are dehumanized in the act of inattention by the State (Cardoso de Oliveira, 2008; Mota, 2012). The State abandons its own in an incomplete intervention/operation, without resources to properly implement social services. The State is only interested because this police force is capable of defending the interests of the companies and the speculation.

By establishing a set of legal social codes that separate the favela from the asphalt in terms of security, and being the black favela as a result of historical segregation, a symbolic distance is imposed between the non-favelado and the favelado, between the white and the black, as in a Jim Crow system ${ }^{7}$, taking effect in public space (Mota, Silva $\&$ Ovalle, 2014). This means that the conduct of the social actors involved must be studied in relation to these symbols and in a context where favelas dwellers find themselves "betwixt and between". In other words, that residents have undergone enormous changes in their local reality, but still, as we have analyzed, have not been fully incorporated into the "asphalt" (Turner, 1967). The maintenance of the border with the favela is therefore the maintenance of a "colored" border. This border governed by concrete interests institutionalizes residential segregation by concentrating broad social segments in "homogeneous areas" (Coelho, 1978). The UPPs, on the one hand, seem to want to break that spatial and social frontier; although on the other hand, they are part of the system by which companies get benefits from favelas residents.

The police function is limited to the security field and mediations are considered bureaucratic procedures. The PM doesn't act considering the principles that the Security Secretariat, the Court of Justice, and the companies had when establishing the agreement (reducing administrative procedures, preventing statistics of larger conflicts, and avoiding the costs of litigation). With the mediations made by the police, the logic of the State and the companies always wins, despite the fact that the conflict is bureaucratized by the PM (Kant de Lima, 2010).

\section{CONCLUSIONS}

The UPPs project seeks to build harmonic forms of relation, preventing the manifestation of violence or injustices to unfold. In doing so, it draws on harmonic ideologies that appear to be more concerned with avoiding the manifestation of conflict, than solving the cause of the conflict itself. As a result, although appearing to offer long-term solutions, grounded on harmonic and consensus approaches, UPPs mediation risks to undermine the underlying conflicts of society, that, from time to time, may re-emerge and expose the structural violence of Brazilian society.

We currently observe a similar phenomenon in Brazil. In spite of the harmonic discourses, the militarism of the country became remarkably pronounced when the President Temer, on February of 2018, declared a military intervention in the State of Rio de Janeiro. At that time, the public perception was that violence was spiralling out of control, leading the Federal Government to assume extreme measures to suppress urban violence in Rio de Janeiro. The president compared the organised crime with a metastasis spreading throughout the country, and signed an extraordinary decree putting military institutions in charge of security in Rio de Janeiro.

\footnotetext{
${ }^{7}$ The Jim Crow System was a series of laws that enforced racial segregation in the United States during the late $19^{\text {th }}$ and early $20^{\text {th }}$ centuries.
} 
It was the beginning of a significant shift from the UPPs rhetoric to a hard-line agenda against violence, drugs, and the favelas. The initial mobilization of conservative and populist discourses that, building on genuine fear among society, openly express its opposition to human rights, appealing to anti-democratic mechanisms and explicit violent discourses.

The election of fair-right president Jair Bolsonaro, on 2018, and the current governor of Rio, Wilson Witzel, is the final expression of this process. Both political projects are grounded on foundational pillars: the extensive use of repressive forces against drugs, and the development of a neoliberal agenda.

This combination, we argue, is also present on the UPP project, finally suggesting that, in Brazil, the violence/pacification discourse is central to the implantation of a neoliberal economic project. In the following line we will briefly outline some explanations for the failure of the UPPs project in order to demonstrate how it is connected to the main point of this article: the fine line between private and public interests.

\section{The failure of the UPPS}

One argument that explains the failure of the UPPs is that, underlying the harmony and cordiality performance, was (and still is) a society constituted on the basis of violence, on deeply rooted inequalities and structural racism. And these issues, we highlight, were undermined - if not ignored - during the implementation of the UPPs policy.

Another explanation lies on the ambiguous approach of the initiative that articulated the State's interests in "pacifying" the favelas with private companies interests. As the project unfolded, private interests gained protagonism, undermining the core principles of an integrated public policy of security.

What the analysed case demonstrates is that, despite of the rhetoric of pacification, in the daily practice of the project, the State became captured, serving exclusively private companies' interests in detriment of public demands. As we demonstrate, it became captured in a dual form: first, in the city level during its decision-making process; and second, in a micro-level, through the instrumentalization of mediation processes.

In the decision-making process, neoliberal urbanism tends to orient its decision towards the maximization of surplus value. In this sense, cities become the result of multinational interests searching new spaces to (re)invest; and urbanism, instead of working towards the redistribution of unequal investments in the overall city, becomes an instrument to attract national and international capital, often reinforcing spatial inequalities. The exclusive presence of the UPPs in the so-called "Olympic belt", the richest areas of the city, demonstrates how this policy was designed to serve primordially private interests - and in this case land speculation - rather than the common interest.

In the local level, as we extensively detail in this article, mediation becomes an instrument for private companies seeking for new customers. In doing so, instead of fulfilling its alternative harmonic claims, in practice, mediation in the favelas serve private interests insofar as it benefit the most powerful part in the negotiation. As we argue, in a win-win situation, residents are finally forced to an agreement, even if considered unfair.

In short, the ambiguous principles followed by the UPPs - that moved between private and public interests - is a key reason for its failure. But even more significant, it illustrates the patrimonialism and clientelism that shapes the Brazilian State; the opaque 
separation between private and public interests, that finally permeates the crafting of the State in multiple levels.

\section{ABOUT THE AUTHORS:}

Mayane Dore is a Brazilian transdisciplinary researcher working across the fields of anthropology and urban design. She is currently a Ph.D. candidate under a cotutelle agreement between Macquarie University and Complutense University. For her thesis, Mayane studies everyday life in democracy doing a participatory redevelopment in Sydney. She also holds a Master of Anthropology from the Federal University of Fluminense, where she studied the urban redevelopment during the Olympic Games in Rio de Janeiro. Email: maydore@ gmail.com

Gabriel Bayarri is Ph.D. candidate in two departments of Anthropology and Sociology: the Macquarie University (Sydney), where he works as casual staff, and the Complutense University (Madrid), where he is an honorific collaborator. His research focuses on the so-called far-right. During the last decade, Gabriel has worked in the Latin American context, specifically in Brazil analyzing its post-colonial structure of power. He is a research fellow in the following research groups: Centre for Research on Extremism (CREX, Oslo University), Centre for Right-Wing Studies (CRWS, University of California, Berkeley), and the Centre for Research into Global Power, Inequality and Conflict (RGPIC, Macquarie University). Email: g.bayarritoscano@gmail.com

Daniel Marías is Graduate in Geography and Diploma of Advanced Studies in Regional Geographic Analysis from the Autonomous University of Madrid and $\mathrm{PhD}$ in the Humanities program of the University Carlos III of Madrid, in whose Department of Humanities: History, Geography and Art is a Lecturer since 2004. Due to my conception of the geographical discipline my professional interests are very varied, although fundamentally I have focused my research and dissemination activity around the following thematic lines: human geography; planning and management of the territory; environment, nature and landscape; historical geography; history of science and education; heritage and tourism. Email: daniel.marias@uc3m.es

This article presents the results of an ethnographic research conducted for the project "Instruments for Interference in the Performance of the Judiciary", supported by CAPES (Coordination for the Improvement of Higher Education Personnel)/CNJ (National Council of Justice).

\section{REFERENCES}

Brenner, Neil \& Theodore, Nik (2002), "Cities and the Geographies of 'Actually Existing Neoliberalism"”, Antipode, Vol. 34, No. 3, pp. 349-379. http://doi.wiley.com/10.1111/1467-8330.00246

Cardoso de Oliveira, Luis R. (2008), “Existe Violência Sem Agressão Moral?”, Revista Brasileira de Ciências Sociais, Vol. 23, No. 67, pp. 135-146. https://doi.org/10.1590/S0102-69092008000200010

Cavalcanti, Mariana (2013), “À Espera, Em Ruínas: Urbanismo, Estética e Política No Rio de Janeiro Da Pacificação", Dilemas: Revista de Estudos de Conflito e Controle Social, Vol. 6, No. 2, pp. 191-228. 
Coelho, Edmundo (1978), "A criminalização da marginalidade e a marginalização da criminalidade”, Revista de Administração Pública, Vol. 12, No. 2, pp. 139-161.

Franquesa, Jaume (2013), Urbanismo Neoliberal, Negocio Inmobiliario y Vida Vecinal. El Caso de Palma, Barcelona: Icaria - Institut català d'Antropologia.

Garland, David (2008), A cultura do controle: crime e ordem social na sociedade contemporânea, Rio de Janeiro: Revan.

Hegel, Friedrich (2003), Principios da Filosofia do Direito, Ed. Martins Fontes.

Kant de Lima, Roberto (2003), "Direitos Civis, Estado de Direito e 'Cultura Policial': a formação policial em questão", Revista Brasileira de Ciências Criminais, Vol. 11, No. 41, pp. 241-256.

Kant de Lima, Roberto (2010), "Sensibilidades jurídicas, saber e poder: bases culturais de alguns aspectos do direito brasileiro em uma perspectiva comparada", Anuário Antropológico, Vol. 35, No. 2, pp. 25-51.

Luci de Oliveira, Fabiana (2012), UPPs, direitos e justiça. Um estudo de caso das favelas do Vidigal e do Cantagalo, Ed. FGV.

Melo, Thiago de Souza (2009), Policiamento Comunitário no Rio de Janeiro - uma estratégia de ampliação do controle social no contexto do neoliberalismo, Dissertação (Mestrado em Sociologia e Direito). Instituto de Ciências Humanas e Filosofia, Universidade Federal Fluminense, Niterói.

Miranda, Ana P. M. \& Dirk, Renato (2010), "Análise da construção de registros estatísticos policiais no Estado do Rio de Janeiro", in Kant de Lima, Roberto et al. (Orgs.), Conflitos, direitos e moralidades em perspectiva comparada, Rio de Janeiro: Garamond, Vol. II.

Misse, Michel (2010), "Crime, sujeito e sujeição criminal: aspectos de uma contribuição analítica sobre a categoria "bandido", Lua Nova, Revista de Cultura e Política, No. 79, pp. 15-38.

Monteiro, Fabiano \& Malanquini, Lidiane (2012), "Sobre Soldados e Gansos: Uma aproximação acerca da percepção policial sobre a atuação em UPPs", Trabalho apresentado na $28^{\mathrm{a}}$ Reunião Brasileira de Antropologia, SP, Brasil.

Mota, Fabio (2012), "Regimes de envolvimento e formas de reconhecimento no Brasil e na França", Antropolítica, Vol. 32, pp. 129-148.

Mota, Fabio; Silva, Sabrina \& Ovalle, Luiza (2014), "Sentidos de Justiça e moralidades investidas: uma etnografia da abordagem policial e a filtragem racial", in Anais do $38^{\circ}$ Encontro Anual da Anpocs, de 27 a 31 de outubro de 2014, em Caxambu, 17 pp.

Nader, Laura (1994), "A Civilização e seus negociadores: a harmonia como técnica de pacificação”, Anais da XIX reunião Brasileira de Antropologia, Niterói, pp. 43-66.

Nascimento, Vânia (2012), "Mediação nas Unidades de Policia Pacificadora. Morro da formiga", Dissertação UFF/ PPGA.

Pujadas, Joan J. \& Baptista, Luís (2000), "Ciudadanía Cosmopolita Frente a Segmentación Multicultural: Multiplicación y Visibilidad de Los Actores Sociales Urbanos", in Muntanola, Josep (Ed.), El Futur de l'arquitecte: Ment, Territori i Societat, Barcelona: UPC, pp. 119-129. 
Pujadas, Joan J. (2005), “Cidades Acolhedoras? Transformações Urbanas, Imaginários e Actores Sociais”, Forum Sociológico, Vol. 14 (II séries), pp. 31-46.

Rolnik, Raquel (2015), Guerra Dos Lugares: A Colonização Da Terra e Da Moradia Na Era Das Finanças, São Paulo: Boitempo.

Turner, Victor (2005), La selva de los símbolos: aspectos del ritual Ndembu. Madrid: Siglo XXI. Traducción castellana de: The forest of Symbols, Nueva York, Ithaca, 1967.

Valladares, Lícia (1994), A Invenção Da Favela, Rio de Janeiro: FGV.

Vaz, Lilian (1994), "Dos Cortiços Às Favelas e Aos Edifícios de Apartamentos - a Modernização Da Moradia No Rio de Janeiro”, Análise Social, Vol. XXIX (127-3), pp. 581-597.

Zaluar, Alba \& Alvito, Marcos (2006), Um Século de Favela, Rio de Janeiro: FGV. 5th ed. 